\title{
PARTISIPASI KONTAK KERUKUNAN SOSIAL (K2S) SUKU JAWA TERHADAP PENDIDIKAN MASYARAKAT ISLAM KOTA KUPANG
}

\author{
Muhammad Tamrin \\ Universitas Muhammadiyah Kupang \\ Email: khasa_tamrin@yahoo.com
}

\begin{abstract}
Essentially, K2S was established to be an unified forum for all Javanese in Kupang City and its surroundings. K2S was a kinship independent social organization which is not affiliated with other social political or community organizations. The main objective of $K 2 S$ was to develop family relations, brotherhood, togetherness and harmonization between K2S members, maintain and develop the values of Javanese art and culture, tradition, supporting faith activities, strengthen worship, and enhance morals of K2S members based on their dogma and it was also for contributions of Kupang city development. This study was done to ascertain the efforts of K2S in improving education of Islamic community in Kupang city. In this qualitative descriptive research, the data was gathered through interviews, observation, and documentation. The data was analyzed use the interactive data analysis models by Milles and Huberman. The study showed that the Javanese social harmony intercaction (K2S) took part in: 1. Social community aspects; 2. member's training and empowerments; 3. spirituality; 4. Arts and culture.
\end{abstract}

Keywords: Participation, Islamic Community Empowerments.

Abstrak
Pada hakekatnya K2S dibentuk untuk dapat menjadi wadah permersatu bagi seluruh warga Jawa yang berdomisili dan berkarya di Kota Kupang dan sekitarnya. K2S adalah organisasi atau paguyuban sosial kemasyarakatan yang bersifat kekeluargaan, mandiri dan tidak terikat dengan organisasi sosial politik maupun organisasi kemasyarakatan lainnya. Adapun tujuan utama terbentuknya K2S adalah Membangun hubungan kekeluargaan, persaudaraan, kebersamaan dan harmonisasi antar anggota, memelihara dan mengembangkan nilai-nilai seni budaya dan adat-istiadat Jawa, mendukung kegiatan yang bersifat keimanan, memperkuat ibadah, dan mempertinggi akhlak anggota sesuai ajaran agamanya serta kontribusi bagi pembangunan Kota Kupang. Penelitian ini bertujuanuntuk mengetahui Upaya yang dilakukan K2S Suku Jawa Kota Kupang dalam meningkatkan pendidikan pada masyarakat Islam kota Kupang. Penelitian ini merupakan penelitian deskriptif kualitatif dengan teknik pengumpulan data melalui metode observasi,wawancaradan dokumentasi. Teknik analisis yang digunakan adalah teknik analisis data interaktif model Milles dan Huberman. Dan dapat disimpulkan bahwa Kontak Kerukunan Sosial (K2S) suku Jawa mengambil peran pada : 1. Aspek Sosial Kemasyarakatan, 2. Pelatihan dan Pemberdayaan Anggota, 3. Kerohanian, 4. Seni dan Budaya.

Kata Kunci: Partisipasi, Pemberdayaan masyarakat Islam 


\section{A. Pendahuluan}

Derap langkah memajukan ekonomi dan pendidikan diwilayah di NTT mengalami stagnasi, berdasarkan Indeks Pembangunan Manusia yang diterbitkan Badan Pusat Statistik 16-04-2018, hingga tahun 2017 NTT berada pada skor 63,73 dengan Indeks Nasional rata-rata 70,81 (www.bps.go.id). Terdapat banyak daerah yang tergolong miskin serta keterbelakangan dalam bidang pendidikan. Kondisi ini menjadi bukti ketidakberdayaan masyarakat dari krisis yang berkepanjangan. Upaya untuk menanggulangi masalah pendidikan dilakukan terus menerus oleh pemerintah dan masyarakat dalam upaya menemukan bentuk yang ideal dalam meningkatkan pendidikan pada masyarakat.

Dalam kehidupan bermasyarakat, biasa sekelompok masyarakat yang berperan sebagai fasilitator dalam mengatasi beragam persoalan kemasyarakatan yang ada dengan menumbuh kembangkan tradisi bergotong royong dalam semangat kedermawanan sosial. Dalam pandangan Burhan Bungin (2006:272), Organisasi atau paguyuban merupakan gabungan sumber daya tenaga manusia yang dengan sumber daya lain, yaitu dengan menjalin para pemimpin, kelompok pengikut atau pekerja, dan sistem serta sturktur. Dalam membangun kesadaran masyarakat kita banyak menjumpai suatu kelompok atau komunitas.Komunitas menurut Jim Ife (2019:11) adalah individu yang melakukan kegiatan atau usaha secara bersama dalam beberapa waktu. Rasa tanggung jawab sebuah komunitas terumuskan dalam "Tradisi saling membantu" dalam berbagai bentuknya dengan tidak hanya terbatas dalam bentuk rupiah atau barang melainkan juga pekerjaan atau berbagai usaha untuk meringankan beban hidup individu atau masyarakat serta meningkatkan kemandirian serta kesejahteraannya.

Partisipasi masyarakat adalah aspek yang terpenting dalam pembangunan masyarakat. Slamet (1994:7) mengartikan partisipasisebagai peran serta individu atau kelompok masyarakat secara aktif dari proses perumusan kebutuhan, perencanaan, sampai pada tahap pelaksanaan kegiatan baik melalui pikiran atau langsung dalam bentuk fisik. Partisipasi merupakan bagian dari penentu juga sebagai indikator keberhasilan pembangunan. Seberapapunbesar upaya pemerintah dalam membangun, jika tidak disertai dengan partisipasi atau tidak didukung oleh masyarakat, maka tingkat keberhasilan program pembangunan 
yang dicanangkan pemerintah lebih kecil dibandingkan jika program-program itu melibatkan patisipasi dari masyarakat.

Kedermawanan sosial baik individu ataupun kelompok merupakanmodal yang telah menyatu didalamtradisimasyrakat yang telah mengakar sejak lama khususnya pada masyarakat Indonesia. Fakta menunjukkan bahwa tradisi "taawwun" saling membantu, gotong royong dilestarikan melalui bantuan kepada keluarga, teman, dan tetangga yang yang membutuhkan. Berpartisipasi dalam pemberdayaan masyarakat juga merupakan bagian dari ajaran agama yang dari segi duniawiyah terlebih dalam hal kemiskinan dan keterbelakangan. Secara fungsional, agama berperanan penting dalam kehidupan masyarakat, baik itu pada masyarakat tradisional maupun modern, agama bagi mereka merupakan tempat mencari makna hidup, sehingga segala bentuk perilaku dan tindakan selalu berdasarkan pada tuntutan agama (wayoflife). Dengan membantu sesama yang sedang membutuhkan, maka perbuatan menolong orang lain yang sedang membutuhkan adalah tindakan mulia.

Kupang sebagai wilayah perkotaan dengan tingkat kemajemukan yang tinggi, tumbuh menjadi kota yang religius, bersinergi serta terus menerus berusa menjalankan sistem pemerintahan demi meningkatkan kesejahteraan dan kemakmuran masyarakat. Maka sejatinya partisipasi ini harus dirasakan oleh seluruh lapisan masyarakat kota Kupang tanpa harus membedakan etnik dan relasi sosial dalam kehidupan sosial.

Gotong royong, berderma serta membantu dalam segala bidang juga tumbuh pada diri masyarakat suku jawa. Untuk mengejahwantahkan prinsip prinsip tersebut maka terbentuklah Organisasi Kemasyarakat (paguyuban) dengan nama Kontak kerukunan Sosial (K2S) Suku Jawa Kota Kupang. K2S dibentuk untuk menjadi wadah permersatu bagi seluruh warga Jawa yang berdomisili dan berkarya di Kota Kupang dan sekitarnya. K2S terbentuk oleh kebersamaan, bersifat kekeluargaan, mandiri dan bukan organisasi politik serta tidak berafiliasi pada partai politik manapun.Namun hal tidak berarti K2S melarang para anggota terlibat dalam partai politik. Partisipasi organisasi ini tidak terbatas pada anggota organisasi melainkan juga padamasyakarat sekitar, bahkan dalam anggaran dasar organisasi termaktub bahwa K2S ikut berpartisipasi aktif dalam kegiatan yang 
diselenggarakan oleh pemerintah Kota Kupang. Rumusan masalah yang diangkat dalam penelitian ini bagaimana partisipasi Kontak Kerukunan Sosial (K2S) suku Jawa terhadap Pendidikan Masyarakat Islam Kota Kupang?

\section{B. Landasan Teori}

\section{Konsep Partisipasi}

Kata "partisipasi"diambil dari bahasa Inggris yaitu "participation" yang berarti pengambilan bagian, pengikutsertaan (John M. Echols dan Hasan Shadily, 2000:419). Menurut I Nyoman Sumaryadi (2010:46) partisipasi adalah peran serta individu atau kelompok masyarakat dalam proses pembangunan baik dalam bentuk pernyataan maupun dalam bentuk kegiatan dengan memberi masukan pikiran, tenaga, waktu, keahlian, modal dan atau materi, serta ikut memanfaatkan dan menikmati hasil-hasil pembangunan.

Adapun Fasli Djalal dan Dedi Supriadi (2001:201-202) memaknai partisipasi sebagai penyampaian yangberbentuk saran, pendapat, barang, keterampilan, bahan dan jasa oleh kelompok atau masyarakat . Jadi partisipasi dapat juga berbahwa kelompok masyarakat dapat mengenal masalah mereka sendiri, mengatasi persoalan, memecahkan masalah, menentukan pilihan dan membuat keputusan pilihan. Dalam pandangan H. A. R. Tilaar (2009:287) partisipasi merupakan wujud dari keinginan untuk mengembangkan demokrasi melalui proses desentralisasi dimana diupayakan perlunya yang perencanaan dari bawah (bottom-up) dengan mengikutsertakan masyarakat dalam proses perencanaan dan pembangunan masyarakat. Sundariningrum dalam Sugiyah (2001:38) membagi partisipasi menjadi 2 (dua), berdasarkan cara keterlibatannya yaitu :

1. Partisipasi Langsung

Partisipasi langsung adalahtiap individu menampilkan kegiatan tertentu sebagai proses partisipasi. Partisipasi ini terjadi jika tiap individu atau personal dapat mengajukan pandangan, membahas pokok permasalahan, mengajukan keberatan terhadap keinginan orang lain atau terhadap ucapannya. 
2. Partisipasi tidak langsung

Partisipasi tidak langsung adalah apabila individu mendelegasikan hak partisipasinya.

Sementara menurut Suparjan (2003:20) bahwa selama ini kesanseseorang sudah berpartisipasi adalah apabila dia sudah terlibat secara fisik seperti ikut kerjabakti, ikut membantu material, ikut menghadiri pengajian. Padahal menurut beliau bahwa esensi yang terkandung dalam partisipasi sebenarnya tidak sesempit itu, ada hal satu hal yang juga penting yaitu konsep partisipasi berpikir atau memberi saran dari individu atau kelompok masyarakat dapatjuga dikatakan sebagai bentuk dari partisipasi.Karna itu menurut beliau partisipasi tidak hanya sekedar dipandang dari sisi fisikal semata.

\section{Pemberdayaan Masyarakat}

John Friedman (1992) dalam Ginanjar K. (1997:55) mengartikan Pemberdayaan sebagai alternative development yang menghendaki 'inclusive democracy, appropriate economic growth, gender equality and intergenerational equaty. Pemberdayaan masyarakat seyogyanya tidak menjadikan masyarakat makin tergantung pada berbagai program pemberian (charity) melainkan untuk menjadikan masyarakat lebih mandiri, dalam meningkatkan untuk memajukan diri menuju arah kehidupan yang lebih baik dan berkesinambungan. Maka pola pendekatan yang dilakukan terhadap konsep pemberdayaan adalah bahwa menjadikan masyarakat sebagai subjek dari berbagai upaya pembangunan sendiri dan tidak menjadikan masyarakat sebagai objek dari berbagai proyek pembangunan.

\section{Masyarakat}

Dalam kamus besar bahasa Indonesimasyarakat adalah sejumlah manusia dalam arti seluas-luasnya dan terikat oleh suatu kebudayaan yang mereka anggap sama. Sementara dalam bahasa inggris disebut society, asal katanya socius yang berarti kawan. Adapun kata "masyarakat" dalam bahasa Arab, memiliki makna yang sama dengan "syirk" yang artinya bergaul. Pergaulan ini tentunya didasari karena ada norma kehidupan yang disepakati, bukan disebabkan oleh manusia sebagai individu, melainkan oleh faktor lain dalam lingkungan sosial masyarkat yang merupakan satu kesatuan. Para ahli sosiologi sepakat bahwa adanya interaksi 
masyarakat, pergaulan yangdidasari oleh adanya nilai-nilai, norma-norma, caracara dan prosedur yang merupakan kebutuhan bersama sehingga masyarakat merupakan satu kesatuan manusia yang hidup dan berinteraksi dalam suatu sistem adat istiadat tertentu, yang bersifat terus menerusserta terikat oleh suatu identitas bersama. Penelitian terdahulu yang relevan dengan penelitian adalah Desertasi Dr. Baco Tang, S.Sos, M.Si berjudul "Migrasi dan Perubahan Sosial" Analisis Sosiologis Tentang Konstribusi Etnik Bugis Bagi Ekonomi Kota Kupang.

\section{Metode Penelitian}

Pendekatan yang digunakan dalam penelitian ini adalah pendekatan deskriptif kualitatif. Penelitian kualitatif menekankan pada proses yang diambil dari fenomena-fenomena di balik realita yang ada, kemudian ditarik kesimpulannya dengan serangkaian kata atau kalimat. Seperti yang dinyatakan oleh Lexy J. Moleong (2007:6) tentang penelitian kualitatif sebagai berikut: penelitian kualitatif ialah penelitian yang bermaksud untuk memahami fenomena tentang apa yang dialami oleh subjek penelitian sepertimotivasi, persepsi,perilaku,tindakan dan yang lainnya, secara holistik, dan dengan cara memapakar dalam bentuk kata-kata dan bahasa pada suatu konteks khusus yang alamiah dengan memenfaatkan berbagai cara alamiah.Sumber data penelitian ini adalahOrganisasi masyarakat K2S (kontak kerukunan sosial) suku Jawa Kota Kupang. Teknik pengumpulan data yang digunakan dalam penelitian ini adalah :1. observasi yaitu mengamati aktivitas serta pola partisipasi dan lainnya.2. Wawancara dengan pimpinan organisasi serta anggota K2S. Adapun teknik analisis data dalam penelitian ini berupa analisis data kualitatif yang memberi keterangan dan penjelasan dari hasil penelitian yang diperoleh dan dapat digunakan untuk kesimpulan dan saran. Proses dan teknik analisis data yang digunakan dalam penelitian ini adalah analisis model Milles dan Huberman

D. Hasil

\section{Keberadaan Organisasi K2S}

Kontak Kerukunan Sosial (K2S) Suku Jawa merupakan suatu wadah organisasi yang terbentuk karena adanya beberapa kesamaan seperti suku, budaya, 
visi, misi, dan ideologi.Karena kesamaan itulah kemudian terbentuklah suatu wadah (paguyuban). Agar gerakan organisasi terpola dengan baik maka ditetapkan tujuan yang sama, struktur, serta menetapkan kebijakan dan program kerjanya dalam mencapai tujuan organisasi.

Dari hasil Pengamatan Peneliti, Kontak Kerukunan Sosial atau disingkat K2S telah memenuhi segala persyaratan terbentuknya organisasi. Kontak Kerukunan Sosial (K2S) Suku Jawa memiliki pendiri sebagai pemrakarsa terbentuknya suatu wadah organisasi, memiliki anggota yang jelas, mempunyai dasar hukum organisasi sebagai aturan main dalam menjalankan organisasi atau yang disebut Anggaran Dasar dan Anggaran Rumah Tangga (AD/ART) organisasi, adanya kepengurusan organisasi. Mempunyai arah kebijakan dan program kerja yang jelas yang berlandaskan pada visi dan misi gerakan, mempunyai sistem kaderisasi dan regenerasi yang berlandaskan pada aspek moralitas, loyalitas, integritas, tanggung jawab, dan prestasi.

K2S terbentuk berawal dari diskusi singkat para sesepuh suku jawa yang ada di kota kupang. Ide ini bermula dari keprihatinan terhadap keberadaan para jamaah suku jawa yang tercerai berai dari komunitas. Terlebih lagi ketika adanya kematian salah satu jamaah suku jawa. Maka,akan sulit sekali untuk melakukan prosesi penguburan karena yang bersangkutan tidak memiliki keluarga atau sanak family.

Pada hakekatnya K2S dibentuk untuk dapat menjadi wadah permersatu bagi seluruh warga suku Jawa yang berdomisili dan berkarya di Kota Kupang dan sekitarnya. K2S adalah organisasi sosial kemasyarakatan yang bersifat kekeluargaan, mandiri dan tidak berafiliasi dengan organisasi politik maupun organisasi kemasyarakatan lainnya (Ad/ART K2S). Adapun tujuan utama terbentuknya K2S adalah Membangun hubungan kekeluargaan, persaudaraan, kebersamaan dan harmonisasi antar anggota, memelihara dan mengembangkan nilai-nilai seni budaya dan adat-istiadat Jawa, mendukung kegiatan yang bersifat keimanan, memperkuat ibadah, dan mempertinggi akhlak anggota sesuai ajaran agamanya serta kontribusi bagi pembangunan Kota Kupang (Ad/ART K2S).

Dari peristiwa kematian inilah kemudian muncul ide bagaimana menghimpun jamaah dari suku jawa untuk membantu proses identifikasi jenazah, 
memandikan jenazah sampai pada penguburan. Berdasarkan penuturan ketua $\mathrm{K} 2 \mathrm{~S}$ Bapak dr. Ihsan bahwa terdapat tokoh yang menjadi sesepuh masyarakat suku jawa yang menjadi inisiator terbentuknya paguyuban ini, diantaranya Bapak Pak wahid, Zainuddin Akid, Pak Raji, dr. Ihsan, Pak Suparman, H. Junaidi, Pak Soni, Pak sugiono, dan H. Yono.

Berdasarkan inisiasi para sesepuh ini terkumpullah dana sebesar Rp. 38.000.000. dari dana ini hal pertama yang dilakukan adalah membeli mobil jenazah seharga Rp. 27.000.000. Sementara sisa keuangan digunakan untuk mendaftar ke Akta Notaris yang diwakili oleh pak Wahid dan pak iskandar. Sehingga menurut dr. Ihsan mereka-mereka yang mendaftar K2S ke Akta notaris sebagai pendiri K2S kota Kupang. Setelah pengadaan mobil ambulan yang pertama terdapat proses-proses yang mengiringinya untuk membentuk paguyuban yang besar. Pada rapat awal telah bergabung beberapa nama yang kemudian membentuk tim kecil dan melakukan rapat lanjutan di rumah Pak Soni untuk menentukan nahkoda paguyuban, dan keputusan rapat adalah memilih dr. Ihsan sebagai ketua.

Namun keputusan ini belum final untuk disepakati oleh semua peserta paguyuban. Tarik menarik kepentingan menyebabkan kepengurusan K2S menjadi vakum beberapa bulan. Dan momen kebersamaan terbentuk ketika pameran budaya yang menampilkan reokponorogo dalam pawai kebudayaan hari jadi kota Kota Kupang, dari sinilah terkumpul semua elemen masyarakat suku Jawa dalam satu wadah Paguyuban Kontak Kerukunan Sosial (K2S) suku Jawa Kota Kupang. Kepengurusan K2S kemudian di Kukuhkan Pada Bulan Oktober 2016. Sampai saat ini menurut ketua K2S kota Kupang dr. Ihsan,Jumlah anggota K2S sekitar 1600 KK.Adapun partisipasi anggota dalam memajukan organisasi ini dengan menarik iuran dengan jumlah minimal Rp. 20.000 bagi anggota biasa dan Rp. 50.000 bagi pengurus K2S. Adapun Faktor Pendukung terbentuknya K2S

1. Kesamaan Suku, budaya dan Bahasa

2. Memiliki Visi dan Misi yang sama Sedangka Faktor Penghambat

1. Perbedaan Karakter

2. Ego dan kepentingan individu 
Hal ini dipertegas dengan hasil hasil wawancara peneliti terhadap Ketua Organisasi K2S dr. Ihsan. Bahwa terdapat kendala yang dihadapi diawal terbentuknya paguyuban K2S yaitu ada 1. Masing masing mempertahankan pendapat 2. Ego yang besar masing masing anggota 3. Perbedaan karekter. Karna menurut beliau anggota K2S terdiri dari semua suku jawa yang berdomisili di Kota Kupang dengan ciri dan watak yang berbeda. Maka lebih lanjut menurut dr. Ihsan, dibutuhkan pemimpin dengan bercirikan: 1. Ngemong (mampu menjembatani kepentingan orang tua dan anak muda) 2. Ikhlas dalam menjalankan dan membesarkan organisasi 3. Independen artinya tidak terjebak dalam pusaran politik praktis dan dukung mendukung. Sebagai organisasi Paguyuban Kontak Kerukunan Sosial (K2S) suku Jawa memiliki programprogram kerja yang terfokus pada 4 kegiatan yaitu :

1. Kegiatan Sosial

2. Pelatihan dan Pemberdayaan Anggota

3. Kegiatan Kerohanian

4. Kegiatan seni dan Budaya

Selain kegiatan diatas K2S juga berpartisipasi membantu pemerintaha daerah dalam pembangunan baik dalam bentuk partisipasi langsung maupun tidak langsung, memberi masukan berupa pikiran-pikiran berkemajuan, tenagaahli, investasi, lapangan kerja, modal dan atau materi, yang berguna untuk keberlangsungan pembangunan.

E. Pembahasan

\section{Partisapasi K2S}

1. Partisipasi Pada Kegiatan Sosial

a. Partisipasi fisik

Adalah partisipasi K2S dalam bentuk menyelenggarakan kegiatan-kegiatan sosial. Dalam praktek penyelenggaran kegiatan masih terfokus kepada masyarakat suku jawa ataupun keluarga yang sudah melakukan perkawinan antara suku. Adapun jenis kegiatan ialah :

1) Pengurusan Jenazah 
Bagi keluarga yang menghendaki jenazah dimakamkan di kampung halaman di pulau Jawa, maka K2S mengurus semua proses administrasi sampai kepada pembiayaan hingga jenazah sampai kepada pihak keluarga si mayit di tanah Jawa. Adapun Jenazah yang dimakamkan di kota Kupang dan sekitarnya di urus oleh anggota paguyuban K2S sekaligus memberi santunan kepada keluarga yang ditinggal.

2) Santunan Kepada Keluarga tidak mampu masyarakat suku jawa kota Kupang yang besarannya disesesuaikan. Proses pengambilan data masyarakat kurang mampu didapat dari kordinator wilayah yang telah mendata seluruh keluarga tidak mampu dan diteruskan kepada pengurus inti. Selanjutnya akan disepakati waktu dan tempat untuk penyaluran sesuai hasil rapat anggota $\mathrm{K} 2 \mathrm{~S}$.

3) Terlibat aktif dalam membantu panti asuhan-panti asuhan yang ada di sekitar kota Kota Kupang baik melalui Organisasi maupun perseorangan.

4) Pembangunan Fisik, Berdasarkan Hasil penelitian belum ditemukan masjid atau lembaga pendidikan formal dikota Kupang yang berada dibawah naungan Paguyuban K2S. Akan tetapi K2S memiliki kegiatan sosial keagamaan yang konkrit seperti membantu Pendirian TPQ dan Majelis Taklim serta masjid dan musholah dikota Kupang. Adapun kegiatan sosial lainnya dilakukan secara insidetil yang tak terprogram. Dari pantuan peneliti, peran Individu anggota K2S lebih menonjol. Hal ini dikarenakan sebelum terbentuk K2S banyak masyarakat suku jawa telah mendirikan lembaga pendidikan non formal untuk membantu meningkatan pengetahuan masyarakat muslim kota Kupang.

b. Partisipasi non fisik

Partisipasi non fisik adalah partisipasi keikutsertaan Paguyuban Kontak Kerukunan Sosial suku Jawa dalam menentukan arah pembangunan kota kupang sehingga pemerintah merasa kehadiran K2S memberi sumbangsih terhadap arah kebijakan sosial kemasyarakatan.

1) Pelatihan dan Pemberdayaan Masyarakat 
Dalam program kerja K2S Pelatihan dan Pemberdayaan masyarakat lebih ditekankan pada anggota paguyuban. Secara statistik jumlah pekerjaan masyarakat suku jawa di Kota Kupang sebagai wirausahawan, dan banyak diantaranya menjadi top leader pada perusahaan swasta dan negeri. Pengusaha-pengusaha yang ada dapat memberikan pengetahuan tentang pengelolaan keuangan serta berperan dalam memfasilitasi terhadap berdirinya usaha kecil dan menengah kepada masyarakat. Dan dalam pengamatan peneliti usaha-usaha yang di kembangkan masyarakat suku Jawa mampu meningkatkan penghasilan daerah dari sektor pajak serta menyerap tenaga secara signifikan.

2) Kegiatan Kerohanian

Kegiatan kerohanian dibagi berdasarkan agama yang dianut oleh anggota K2S. Berdasarkan itu maka dalam program kegiatan kerohanian diberikan kewenangan khusus kepada divisi kerohanian dalam menjalan aktivitas kerohanian. Dalam penelitian yang difokuskan pada kegiatan kerohanian islam. Maka ditemukan beberapa jenis kegiatan yang mengarah pada pemberdayaan masyarakat muslim kota kupang.

a) Pendirian Majlis Taklim

Majlis Taklim merupakan Majelis Taklim merupakan suatu wadah dakwah yang menyelenggarakan pendidikan agama dengan ciri-ciri sebagai berikut:non-formal, tidak teratur waktu belajarnya, para pesertanya disebut jamaah, dan bertujuan khusus untuk usaha memasyarakatkan Islam (Siregar dan Shofiuddin, 2003: 16). Maka dapat dikatakan bahwa majelis taklim merupakan tempat melangsungkan proses belajar para jamaah yang bertujuan mendapat ilmu pengetahuan agama sekaligus tempat berinteraksi antar sesama.

Majelis taklim yang berada di tengah-tengah masyarakat bertujuan untuk menambah ilmu pengetahuan keagamaan dan meneguhkan keyakinan beragama, memotifasi kesadaran beragama, serta sebagai ajang silaturahmi anggota masyarakat dan untuk meningkatkan kesadaran dan kesejahteraan rumah tangga dan lingkungan jamaahnya (Alawiyah, 1997:78). Masih dalam konteks 
yang sama, majelis taklim khususnya di kota kupang berguna dalam rangka membina dan mengembangkan keilmuan, membina kerukunan kehidupan beragama, membentuk pribadi umatyang teguh menjalan syariat agama, sebagai taman rohani, ajang silaturrahim antara sesama muslim, dan menyampaikan gagasan-gagasan yang bermanfaat bagi pembangunan umat dan bangsa. Sementara itu, maksud diadakannya majelis taklim menurut M. Habib Chirzin (2000:77) adalah:

(1) Meletakkan dasar keimanan dalam ketentuan dan semua hal-hal yang gaib;

(2) Semangat dan nilai ibadah yang meresapi seluruh kegiatan hidup manusia dan alam semesta;

(3) Sebagai inspirasi, motivasi dan stimulasi agar seluruh potensi jamaah dapat dikembangkan dan diaktifkan secara maksimal dan optimal dengan kegiatan pembinaan pribadi dan kerja produktif untuk kesejahteraan bersama;

(4) Segala kegiatan atau aktifitas sehingga menjadi kesatuan yang padat dan selaras.

Dakwah merupakan upaya sadar, sistematik, dan terus menerus sampai hari kiamat. Dakwah wajib dilakukan orang beriman dalam membangun kesadaran beragama untukmewujudkan masyarakat yang Islami sekaligus komunitas Islam yang benar-benar menjadi Islam dalam arti tunduk dan patuh kepada Allah SWT dan menyembah kepadanya. Majelis taklim sebagai salah satu wadah gerakan dakwah juga sering disebut sebagai sentral pembelajaran ke-Islaman (Islamic learning institution).

Sebagai pusat pembelajaran Islam, majelis taklim diakui telah menyumbangkan peran yang amat besar dalam mencerdaskan kehidupan masyarakat muslim kota Kupang, khususnya dalam pengajaran agama dan penguatan akhlak karimah. Keberadaan majelis taklim dalam masyarakat muslim kota Kupang telah membawa manfaat dan kemaslahatan, terlebih bagi kaum perempuan, apalagi bagi mereka yang menjadi anggota dan jamaahnya. Pengembangan 
dakwah merupakan salah satu perilaku manajerial yang meliputi pelatihan yang digunakan sebagai sarana untuk meningkatkan kemampuan keagamaan seseorang dan memudahkan pengembangan nilai kekeraban dalam Islam. Majelis Taklim mengontrol keakuan dalam individu, memanejnya menjadi sebuah kekuatan dalam komunitas yang bertujuan yang sama. Majelis Taklim yang didirikan komunitas K2S mengemban misi dakwah Islam Rahmatan lil Alamin, yaitu Islam yang berkemajuan dan mendamaikan.

Untuk dapat melaksanakan pengembangan dan peningkatan dakwah ini, majelis taklim terus melakukan inovasi dan pembaruan terhadap peningkatan kualitas SDM anggota jamaah serta mendesain strategi dan pendekatan dakwah bervariasi dan partisipatifyang tepat dan efektif dengan media komunikasi terbaru. Secara sadar gerakan dakwah ini terpatri dalam jiwa para anggota K2S. Berdasarkan sejarah K2S terbentuk dari pengajian rutin yang dikembangkan oleh warga suku jawa. Lebih tepatnya adalah majelis taklim sebagai wadah dalam menghimpun warga suku jawa kota kupang. Berdasarkan hasil pantuan peneliti terdapat puluhan majelis taklim yang diselenggarakan masyarakat suku jawa kupang. Akan tetapi banyak diantara majelis taklim itu berkembang berdasarkan asal daerah. Dalam pengamatan peneliti majelis taklim tertua adalah majelis taklim warga Ngawi. Sementara majelis yang paling banyak jamaahnya adalah majlis taklim Al Ikhlas Bakunase Kota Kupang yang dipimpin oleh Bapak Iskandar sekaligus sebaga stakeholder pendiri K2S suku Jawa Kota Kupang.

b) Pendirian Taman Pendidikan Al-Qur'an

Taman Pendidikan Al-Qur'an (TPQ) yang ada di Kota Kupang banyak di Prakarsai oleh Anggota K2S. Kesadaran terhadap keberadaan sebagai penduduk minoritas menggugah untuk mendirikan lembaga TPQ sebagai benteng akidah terhadap anak. Anak sebagai asset dan penerus gerakan dakwah harus diberi pemahaman terhadap akidah dan agama sejak kecil, hal ini diharapkan agar kelak dalam 
pergaulan dimasyarakat tidak terkontaminasi dengan pemahaman yang lain. Keberadaan TPQ ini menjadi tempat belajar anak muslim dan arena aktualisasi nilai kebersamaan sebagai saudara se-akidah walaupun berbeda suku, ras dan golongan. Dalam membina anak-anak supaya memiliki akhlak terpuji perlu melibat mereka dalam komunitas yang memiliki visi yang sama. Perilaku anak akan banyak di pengaruhi oleh lingkungan sekitarnya. Pengenalan lingkungan yang baik akan terpatri dalam benak anak sebagai langkah awal dalam mendidik anak muslim. Dengan kebiasaan yang baik serta latihan dalam yang terus diajarkan dalam TPQ akan membuat anak cenderung melakukan yang baik dan meninggalkan yang buruk.

c) Komitmen Terhadap Pengembangan Dunia Pendidikan

Dari data yang didapat jenis pekerjaan yang banyak digeluti masyarakat suku Jawa kota Kupang adalah berniaga. Selain itu banyak diantara mereka menjadi guru dan dosen. Dari hasil penelitian sementara, terdapat guru dan dosen yang berasal dari suku jawa disetiap lembaga pendidikan yang ada di kota kupang, bahkan menjadi ujung tombak berdirinya lembaga pendidikan Islam di kota kupang.

Kota Kupang terdapat beberapa lembaga pendidikan Islam, 1 Madrasah Aliyah (MAN), 2 Madrasah Tsanawiyah, 4 Madrasah Ibtidaiyah, SMA Muhammadiyah, SMK Muhammadiyah, SMP Muhammadiyah dan SD Muhammadiyah. Dari semua sekolah/lembaga pendidikan terdapat guru/pendidik yang berasal dari suku jawa. Bahkan menjadi tulang punggung gerakan dakwah melalui pendidikan. Diantaranya, Mantan Rektor Universitas Muhammadiyah, Kepala SMP, SMK Muhammadiyah, Kepala MI, Ketua Pimpinan Wilayah Muhammadiyah NTT bahkan penggerak Pondok Tahfiz Kota Kupang.

Kondisi geografis dan keadaan ekonomi masyarakat NTT mengharuskan totalitas dalam memajukan masyarakat muslim. Semangat dakwah dan perjuangan serta pengorbanan menjadi hal yang lumrah bagi individu yang tergabung dalam paguyuban K2S. 
Individu dalam K2S memiliki tingkat partisipasi yang tinggi dalam sumbangsih materi dan pemikiran pada masyarakat Muslim di Kota Kupang.

Berdasarkan kondisi diatas maka K2S berkomitmen :

1. Berpartisipasi terciptanya pendidikan yang bermutu untuk mewujudkan anak didik sebagai generasi cerdas dan berakhlakul karimah.

2. Berperan dan berpartisipasi, terhadap usaha-usaha untuk pembangun fisik baik prasarana dan sarana pendidikan, TPQ, Masjid, kebutuhan buku-buku pelajaran dan literasi.

3. Mendorong berdirinya lembaga pendidikan informal untuk dapat menyelenggarakan pelatihan, kursus-kursus keterampilan, latihan kepemimpinan dan lokakarya, seminar atau sejenisnya yang bersifat ilmiah untuk anggota dan masyrakat muslim lainnya..

4. Mengupayakan K2S secara mandiri dapat memiliki sendiri saranasarana pendidikan formal dan non-formal.

5. Mendorong terciptanya kebijakan pendidikan yang berkemajuan di seluruh wilayah kota Kupang khususnya dan Pemerintah Provinsi Nusa Tenggara Timur pada umumnya, untuk keluar dari keterpurukan dan keterbelakangan.

6. Berperan dalam meningkatkan Akhlaq terpuji dengan mengedepankan budaya kromo pada masyarakat muslim Kota Kupang.

2. Pengembangan Seni Budaya

K2S sebagai wadah besar suku jawa yang memiliki beragam seni dan budaya. Sebagai wadah pemersatu K2S membentuk sanggar seni yang didalam mencakup seluruh seni budaya dari seantero suku Jawa. Seperti Reok Ponorogo, kesenian Banyuwangi dan sebagainya. Adapun pementasan seni ini dipentaskan pada momen-momen penting seperti ulang tahun Kota Kupang, Maulid Nabi Muhammad dan hari bersejarah lainnya. 


\section{F. Kesimpulan}

Paguyuban/organisasi masyarat Kontak Kerukunan Sosial (K2S) suku Jawa Kota Kupang merupakan sebuah wadah bagi seluruh masyarakat suku Jawa yang ada di Kota Kupang. Paguyuban ini terbentuk berdasarkan kesamaan kesamaan suku, bahasaserta visi dan misi. Tujuan utama terbentuknya K2S adalah Membangun hubungan kekeluargaan, persaudaraan, kebersamaan dan harmonisasi antar anggota, memelihara dan mengembangkan nilai-nilai seni budaya dan adat-istiadat Jawa, mendukung kegiatan yang bersifat keimanan, memperkuat ibadah, dan mempertinggi akhlak anggota sesuai ajaran agamanya serta kontribusi bagi pembangunan Kota Kupang. Adapun partisipasi pada pendidikan masyarakat muslim kota Kupang adalah membentuk majelis taklim dan Taman Pendidikan Al-Qur'an, mendorong percepatan kemajuan pendidikan dengan melibatkan organisasi atau individu serta sumbangan materi terhadap pembangangunan fisik lembaga-lembaga keagamaan. Saran peneliti, sebagai gerakan social maka K2S terus konsisten terhadap isu-isu sosial masyarakat, melebarkan sasaran gerakan partispasi yang terfokus kepada anggota melainkan kepada seluaruh masyarakat kota kupang serta tidak memanfaatkan organisasi untuk kepentingan individu.

\section{Daftar Pustaka}

Fasli Jalal dan Dedi Supriadi. 2001. Reformasi Pendidikan dalam Konteks Otonomi Daerah. Yogyakarta. Adicita.

Friedmann, John. 1981. Kemiskinan Urban di Amerika Latin, dalam Andre Bayo Ala (ed). Kemiskinan dan Strategi Memerangi Kemiskinan, Yogyakarta. Liberti

H.A.R. Tilaar. 2009. Pengembangan Sumber Daya Manusia Dalam Era Globalisasi, Jakarta. PT. Grasindo, Cet. Ke-1, h.287.

I Nyoman Sumaryadi. 2010. Sosiologi Pemerintahan : dari prespektif pelayanan, pemberdayaan, interaksi, dan system kepemimpinan Indonesia, Bogor: Galia Indonesia.

Jim Ife dan Frank Tesorio. 1995. Community Alternatif Pengembangan Masyarakat di Era Globalisasi. Jogyakarta. Pustaka Pelajar

John M. Echols dan Hassan Shadili. 1996. Kamus Inggris Indonesia, Jakarta. PT. Gramedia, Cet. Ke-23

Moleong, Lexy J. 2007. Metodologi Penelitian Kualitatif. Bandung. PT. Remaja Rosdakarya. 
Noor, Munawar. Pemberdayaan Masyarakat. 2011. Jurnal Ilmiah CIVIS, Volume I, No 2, Juli 2011:87-99

Slamet Y, 1994. Pembangunan Masyarakat Berwawasan Partisipasi, Surakarta. Sebelas Maret University

Sundariningrum. 2001. Partisipasi Masyarakat. Yogjakarta. Pustaka Pelajar

Sondang P. Siagian. 1980. Filsafat Administrasi, Gunung Agung; Jakarta 